\title{
Taxan-associated nail toxicity
}

\author{
Bernhard Doleschal, Andreas Petzer, Karl J Aichberger
}

Krankenhaus der Barmherzigen Schwestern Linz, Linz, Austria

\section{Correspondence to} Dr Bernhard Doleschal, bernhard.doleschal@gmail.com

Accepted 20 January 2017

\section{DESCRIPTION}

A woman aged 69 years treated with adjuvant docetaxel every 3 weeks for luminal-B breast cancer, presented with nail dystrophies.

On clinical examination, nested nail plates (figure $1 \mathrm{~A}, \mathrm{C}$ ) divided by deep transverse sulci (figure $1 \mathrm{~B}, \mathrm{D})$ on all 10 fingers were prominent. We counted three parallel grooves (figure $1 \mathrm{~B}, \mathrm{D}$ ) with different distance to each other corresponding to three applied cycles of docetaxel. The second cycle of chemotherapy had to be postponed for 1 week due to febrile neutropenia reflected by a wider distance from the first to second than the second to third groove (figure 1A, C).

This case represents the most common variant of taxan-induced nail changes-Beau's lines-transverse linear depressions caused by transient growth arrest of the nail matrix. The extent of these transverse linear depressions correlates well with cytotoxic intensity. In addition, the spectrum of taxan-induced nail alterations includes nail pigmentation, splinter haemorrhage and subungual haematoma, acute paronychia and onycholysis. ${ }^{12}$

The incidence of taxan-induced nail changes increases with duration of therapy and is finally reported to occur in up to $44 \%$ of treated patients. ${ }^{1}$ After cessation of chemotherapy, nail dystrophies usually take a benign course and nail growth usually fully recovers.
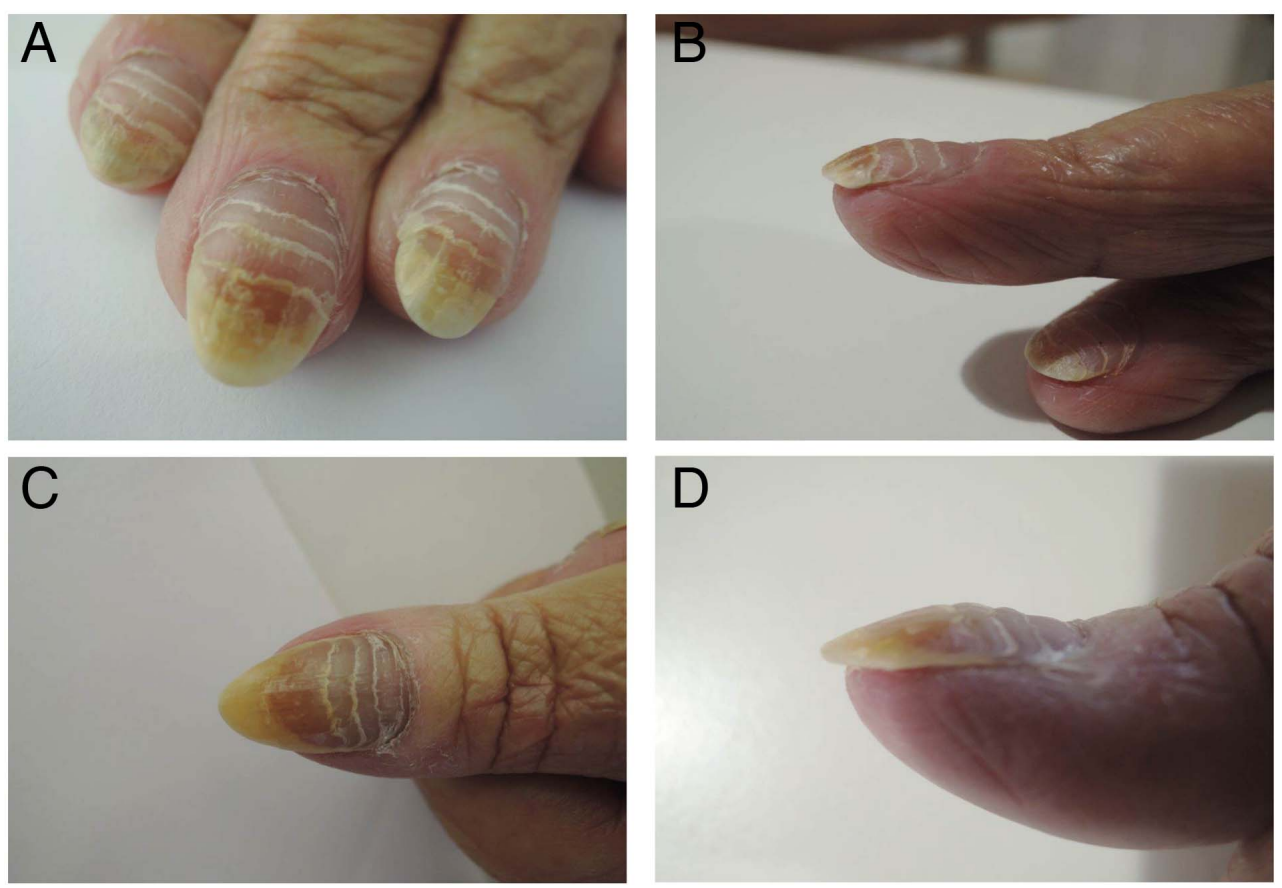

Figure 1 Nail plates divided by deep transverse impressions following the interval of docetaxel application (A-D). Orange discolouration at the distal nail plate, mainly due to subungual haemorrhages $(A, C)$. Additionally, paronychial erythema surrounds some of the nails beds $(A, B)$.
Beau's lines are not a specific chemotherapeutic side effect but rather mirror a state of toxic effect on nail growth. Nutritional deprivation, acute infections or systemic inflammation-often observed in patients Possible therapeutic strategies may therefore include micronutritional supplementation (eg, biotin, vitamin $\mathrm{D}$, zinc) to support nail matrix proliferation.

In our case, we advised to avoid repeated trauma on nails like nail biting, excessive nail manufacturing or extensive water contact.

\section{Learning points}

Side effects of systemic chemotherapy often manifest in alterations of the nail unit, occurring in up to $44 \%$ of patients receiving taxanes. Beau's lines-transverse grooves on the nail surface-are one of the most prominent changes.

- Chemotherapy cycles lead to multiple parallel Beau's lines and variations in the distance or depths of the groove indicate delay or dose reduction in therapy.

- Front-line treatment comprises various physical measures and possibly nutritional supplementation. with cancer-can aggravate impaired nail growth. ${ }^{3}$
To cite: Doleschal $B$, Petzer A, Aichberger KJ. BMJ Case Rep Published online: [please include Day Month Year] doi:10.1136/ bcr-2016-218980 
Contributors BD wrote the manuscript. KJA revised the manuscript. AP revised the manuscript and all authors participated in patient care.

Competing interests None declared.

Patient consent Obtained.

Provenance and peer review Not commissioned; externally peer reviewed.

\section{REFERENCES}

1 Minisini AM, Tosti A, Sobrero AF. Taxane-induced nail changes: incidence, clinical presentation and outcome. Ann Oncol 2003;14:333-7.

2 Robert C, Sibaud V, Mateus C, et al. Review Nail toxicities induced by systemic anticancer treatments. Lancet Oncol 2015;16:e181-9.

3 Geyer AS, Onumah N, Uyttendaele $\mathrm{H}$, et al. Modulation of linear nail growth to treat diseases of the nail. J Am Acad Dermatol 2004;50:229-34.

Copyright 2017 BMJ Publishing Group. All rights reserved. For permission to reuse any of this content visit http://group.bmj.com/group/rights-licensing/permissions.

BMJ Case Report Fellows may re-use this article for personal use and teaching without any further permission.

Become a Fellow of BMJ Case Reports today and you can:

- Submit as many cases as you like

- Enjoy fast sympathetic peer review and rapid publication of accepted articles

- Access all the published articles

- Re-use any of the published material for personal use and teaching without further permission

For information on Institutional Fellowships contact consortiasales@bmjgroup.com

Visit casereports.bmj.com for more articles like this and to become a Fellow 